\title{
Clonal structure in the moss, Climacium americanum Brid.
}

\author{
Thomas R. Meagher* and \\ Jonathan Shaw $\dagger$
}

* Department of Biological Sciences, Rutgers University, P.O. Box 1059 , Piscataway, NJ 08855-1059.

$\dagger$ Department of Biology, Ithaca College, Ithaca, NY 14850.

The present study focussed on the moss species, Climacium americanum Brid., which typically grows in the form of mats or clumps of compactly spaced gametophores. In order to determine the clonal structure of these clumps, the distribution of genetic variation was analysed by an electrophoretic survey. Ten individual gametophores from each of ten clumps were sampled in two locations in the Piedmont of North Carolina. These samples were assayed for allelic variation at six electrophoretically distinguishable loci. For each clump, an explicit probability of a monomorphic versus a polymorphic sample was estimated based on allele frequencies in our overall sample. Although allelic variation was detected within clumps at both localities, our statistical results showed that the level of polymorphism within clumps was less than would be expected if genetic variation were distributed at random within the overall population.

\section{INTRODUCTION}

It has been recognized that in many taxa asexual propagation as the predominant means of reproduction does not necessarily lead to genetic monomorphism (Bell, 1982; Silander, 1979; Vrijenhoek, 1984). Indeed, localized patterns of allozymic variation have been useful tools for identifying the spatial extent of individual clones within plant populations (Silander, 1979) and for recognizing different clones in unisexual fish populations (Vrijenhoek et al., 1978). In order to understand how genetic variation is maintained in asexual populations, it is first necessary to determine the distribution of such genetic variation and relate that distribution to the overall breeding system.

Most species of mosses are believed to reproduce both sexually by spore formation, and asexually by a variety of methods (Longton, 1976; Wyatt, 1982; Wyatt and Anderson, 1984). Asexual reproduction in this group can occur by vegetative fragmentation, in which pieces of gametophytic plants are broken off and reestablish elsewhere, by the formation and dispersal of specialized reproductive structures such as axillary gemmae or rhizoidal tubers (Correns, 1899), or by the growth of localized clones. Moreover, within the approximately 50 per cent of moss species that are hermaphroditic, self-fertilization of bisexual gametophytes results in completely homozygous sporophytes. Dispersal of such genetically identical spores is functionally equivalent to asexual reproduction.

Mosses are believed to be relatively depauperate in genetic variation (Crum, 1973), a circumstance which may reflect the predominance of asexual propagation as the most successful life history mode. Many bryophyte systematists believe that mosses evolve relatively slowly (Anderson, 1963; Khanna, 1964), a view based largely on biogeographic observations. The geographic distributions of most species are relatively broad, and intercontinental range disjunctions without morphological differentiation are common. While some bryologists have assumed that almost all moss reproduction is by means other than sexual spores (e.g., Anderson, 1963), extremely little information is available about how mosses actually do reproduce under natural conditions.

Bryophytes in general, and mosses in particular, have been increasingly recognized as useful organisms for studying a variety of concepts in population biology (During and van Tooren, 1987; Wyatt, 1982). The reasons for this recent increase in awareness of mosses as research tools are 
several-fold. These plants exhibit unusual features for terrestrial plants, such as a conspicuous alternation of generations with the haploid form perennial and freeliving. Since the predominant growth form is haploid, population genetic studies are greatly simplified. Also, this group has been relatively overlooked so that virtually any population biology study represents a novelty.

Ironically, the fact that mosses have been relatively understudied is a weakness as well as a strength. Even basic information about population structure and dynamics are poorly understood for many species, hindering detailed investigations. Many moss species occur as compact clumps of gametophores. The genotypic composition of such clumps, however, is generally not known. Each clump could represent a collection of clonal ramets of the same genotype (as is commonly assumed in many bryological studies) or, alternatively, they could represent an aggregation of co-occurring distinct genotypes. The differences between these possibilities have significant and obvious ramifications for microevolutionary processes in moss populations.

The present study was focussed on the moss species, Climacium americanum Brid., commonly known as the "tree moss" because of its dendroid growth form. Sexual reproduction, as evidenced by sporophyte formation, is extremely rare in $C$. americanum (Shaw et al., 1987). The species occupies a broad geographic range in the eastern United States, from Nova Scotia and Wisconsin south to Florida and Kansas (Crum and Anderson, 1981). The typical growth habit for this species is the formation of discreet mats or clumps along stream margins and on flood plains. These clumps are generally small ( $c a .<60 \mathrm{~cm}^{2}$ ), but are occasionally more extensive. In order to determine the genetic structure of these clumps in C. americanum, the distribution of genetic variation was analysed by an electrophoretic survey of two natural populations.

\section{MATERIALS AND METHODS}

Clumps of C.americanum were sampled in two locations in the Piedmont of North Carolina. The first sample site was on the flood plain of the Eno River $50 \mathrm{~m}$ downstream from its intersection with Guess Road in the city of Durham (Durham County, NC). The second sample site was located in the Korstian Division of the Duke Forest (Orange County, NC) along New Hope Creek approximately $200 \mathrm{~m}$ upstream from where the creek crosses Old Erwin Road. The ecological features of these sites were similar to those described for nearby populations of $C$. americanum characterized in Shaw et al. (1987). In each site, ten individual gametophores were sampled from each of ten distinct clumps. Clumps ranged in size from $13 \mathrm{~cm}$ to $100 \mathrm{~cm}$ in diameter, and gametophores were sampled evenly over a $13 \mathrm{~cm}$ diameter portion of each clump. These gametophores were placed in plastic vials and stored at $-70^{\circ} \mathrm{C}$ for several weeks until they were subjected to electrophoretic analysis.

Enzyme extraction was performed by grinding each sample in liquid nitrogen and then suspending them in an extraction buffer of $0.1 \mathrm{M}$ tris- $\mathrm{HCl}$ $(p \mathrm{H} \mathrm{7 \cdot 2)}$ buffer with 0.5 per cent mercaptoethanol. Extracts were absorbed onto filter paper wicks which were loaded directly into 12 per cent horizontal starch gels. Following electrophoresis, enzyme assays were conducted for six systems that had been found in our previous investigation to be polymorphic: alcohol dehydrogenase $(\mathrm{ADH})$, acid phosphatase (ACP), fluorescent esterase $\left(E_{S T}\right)$, peroxidase (PER), phosphoglucomutase (PGM), and superoxide dismutase (SOD). The electrophoretic and staining protocols for C. americanum are outlined in detail in Shaw et al. (1987).

For each clump, an explicit probability of observing a monomorphic versus a polymorphic sample was estimated based on allele frequencies in our overall sample. For a haploid organism, these probabilities for a given sample size can be calculated by use of a binomial expansion series (table 1; Feller, 1968). Thus for a sample of $n$ gametophores, and a diallelic locus with allele frequencies $p_{1}$ and $p_{2}$, the probability of monomorphism would be

$$
P_{i}(\text { monomorphism })=\left(p_{1}^{n}+p_{2}^{n}\right)
$$

for the $i$ th locus. A combined probability across multiple loci can be obtained by multiplying

Table 1 Probability distribution of a sample of 10 haploid genotypes within clumps based on population allele frequencies $p_{1}$ and $p_{2}$

\begin{tabular}{llll}
\hline $\begin{array}{l}\text { Ratio of } \\
g_{1} \text { to } g_{2}\end{array}$ & Probability & $\begin{array}{l}\text { Ratio of } \\
g_{1} \text { to } g_{2}\end{array}$ & Probability \\
\hline $10: 0$ & $p_{1}^{10}$ & $4: 6$ & $210 p_{1}^{4} p_{2}^{6}$ \\
$9: 1$ & $10 p_{1}^{9} p_{2}$ & $3: 7$ & $120 p_{1}^{3} p_{2}^{7}$ \\
$8: 2$ & $45 p_{1}^{8} p_{2}^{2}$ & $2: 8$ & $45 p_{1}^{2} p_{2}^{8}$ \\
$7: 3$ & $120 p_{1} p_{2}^{3}$ & $1: 9$ & $10 p_{1} p_{2}^{9}$ \\
$6: 4$ & $210 p_{1}^{6} p_{2}^{4}$ & $0: 10$ & $p_{2}^{10}$ \\
$5: 5$ & $252 p_{1}^{5} p_{2}^{5}$ & & \\
\hline
\end{tabular}


together all of the $P_{i}$, assuming the loci are unlinked. A combined probability that a clump will be polymorphic for at least one locus can be obtained by subtracting the combined probability of monomorphism from 1 . Within each site, explicit probabilities of monomorphism versus polymorphism were calculated for each clump sampled using the cumulative allele frequencies observed for that site. Clumps varied in these probabilities due to small differences in sample size.

\section{RESULTS}

Four of the six enzymes assayed showed polymorphism in the Eno River collection, whereas all six were polymorphic in the New Hope Creek collection (table 2). In both populations, allelic

Table 2 Cumulative allele frequencies in the current sampled clumps of Climacium americanum. Allele numbering follows Shaw et al., 1987. Sample sizes $(N)$ vary due to uneven scorability of gels

\begin{tabular}{|c|c|c|c|c|c|c|}
\hline \multirow{3}{*}{ Enzyme } & \multicolumn{3}{|c|}{ Eno river } & \multicolumn{3}{|c|}{ New Hope Creek } \\
\hline & \multirow[t]{2}{*}{$N$} & \multicolumn{2}{|c|}{ Alleles } & \multirow[t]{2}{*}{$N$} & \multicolumn{2}{|c|}{ Alleles } \\
\hline & & 1 & 2 & & 1 & 2 \\
\hline $\mathrm{ADH}$ & 37 & $1 \cdot 00$ & - & 99 & $0 \cdot 27$ & 0.73 \\
\hline $\mathrm{ACP}$ & 94 & 0.89 & $0 \cdot 11$ & 100 & $0 \cdot 10$ & 0.90 \\
\hline $\mathrm{EST}_{\mathrm{f}}$ & 50 & - & 1.00 & 98 & 0.59 & 0.41 \\
\hline PER & 100 & 0.85 & $0 \cdot 15$ & 99 & $0 \cdot 26$ & 0.74 \\
\hline PGM & 100 & 0.90 & $0 \cdot 10$ & 100 & $0 \cdot 10$ & 0.90 \\
\hline SOD & 100 & 0.90 & $0 \cdot 10$ & 97 & $0 \cdot 20$ & 0.80 \\
\hline
\end{tabular}

variation was predominantly due to variation between clumps rather than to variation within clumps (tables 3-4).

In our previous results (Shaw et al., 1987) demonstrated that two varieties of $C$. americanum which differ in morphology can also be distinguished by their enzyme phenotypes coded by several loci. In the Eno River sample, nine of the clumps showed a PGM enzyme pattern characteristic of Climacium americanum var. americanum and the remaining clump was clearly var. kindbergii. Within clump allelic variation was restricted to the PER locus, although allelic variation among clumps was observed for ACP, PGM, and SOD as well (table 3).

At New Hope Creek, the PGM banding pattern (plus morphological characteristics) showed that nine clumps were var. kindbergii and the remaining clump was var. americanum. Within clump variation occurred for ADH, PER and SOD, and overall allelic variation was also observed for ACP and $\mathrm{EST}_{\mathrm{fl}}$, in addition to the morph difference in the PGM (table 4).

Two series of expected frequencies of monomorphic clumps were determined for each population (table 5). In the first series, allelic variation at all loci, including the morph differences at the PGM locus, were used to estimate expected monomorphism. This analysis showed a significant excess of monomorphic clumps in both populations. In the second series, only the most frequent morph type in each sample was used, and allelic variation at the PGM locus was not included. When

Table 3 Allelic variation within and among clumps of Climacium americanum collected along the Eco River, Durham County, NC. Genetic status of clump is indicated as monomorphic (M) or polymorphic (P)

\begin{tabular}{|c|c|c|c|c|c|c|c|c|c|c|c|}
\hline \multirow[b]{2}{*}{ Enzyke } & \multirow[b]{2}{*}{ Allele } & \multicolumn{10}{|c|}{ Clump } \\
\hline & & 1 & 2 & 3 & 4 & 5 & 6 & 7 & 8 & 9 & 10 \\
\hline \multirow[t]{2}{*}{$\mathrm{ADH}$} & 1 & 2 & - & - & 1 & 6 & 10 & 10 & - & - & 8 \\
\hline & 2 & 0 & - & - & 0 & 0 & 0 & 0 & - & - & 0 \\
\hline \multirow[t]{2}{*}{ ACP } & 1 & 10 & 10 & 10 & 10 & 0 & 10 & 4 & 10 & 10 & 10 \\
\hline & 2 & 0 & 0 & 0 & 0 & 10 & 0 & 0 & 0 & 0 & 0 \\
\hline \multirow{2}{*}{$\mathrm{EST}_{\mathrm{f}}$} & 1 & - & 0 & 0 & 0 & 0 & - & - & 0 & - & - \\
\hline & 2 & - & 10 & 10 & 10 & 10 & - & - & 10 & - & - \\
\hline \multirow[t]{2}{*}{ PER } & 1 & 8 & 10 & 10 & 10 & 10 & 10 & 0 & 9 & 10 & 8 \\
\hline & 2 & 2 & 0 & 0 & 0 & 0 & 0 & 10 & 1 & 0 & 2 \\
\hline \multirow[t]{2}{*}{ PGM } & 1 & 10 & 10 & 10 & 10 & 10 & 10 & 0 & 10 & 10 & 10 \\
\hline & 2 & 0 & 0 & 0 & 0 & 0 & 0 & 10 & 0 & 0 & 0 \\
\hline \multirow[t]{2}{*}{ SOD } & 1 & 10 & 10 & 10 & 10 & 10 & 10 & 0 & 10 & 10 & 10 \\
\hline & 2 & 0 & 0 & 0 & 0 & 0 & 0 & 10 & 0 & 0 & 0 \\
\hline \multicolumn{2}{|c|}{ Genetic status } & $\mathrm{P}$ & M & $\mathrm{M}$ & $\mathbf{M}$ & $\mathrm{M}$ & M & M & $\mathbf{P}$ & M & $\mathbf{P}$ \\
\hline
\end{tabular}


Table 4 Allelic variation within and among clumps of Climacium americanum collected along New Hope Creek, Orange County, NC. Genetic status of clump is indicated as monomorphic (M) or polymorphic (P)

\begin{tabular}{|c|c|c|c|c|c|c|c|c|c|c|c|}
\hline \multirow[b]{2}{*}{ Enzyme } & \multirow[b]{2}{*}{ Allele } & \multicolumn{10}{|c|}{ Clump } \\
\hline & & 1 & 2 & 3 & 4 & 5 & 6 & 7 & 8 & 9 & 10 \\
\hline \multirow[t]{2}{*}{$\mathrm{ADH}$} & 1 & 0 & 0 & 10 & 7 & 0 & 0 & 0 & 10 & 0 & 0 \\
\hline & 2 & 10 & 10 & 0 & 2 & 10 & 10 & 10 & 0 & 10 & 10 \\
\hline \multirow[t]{2}{*}{$\mathrm{ACP}$} & 1 & 0 & 0 & 0 & 0 & 0 & 0 & 0 & 0 & 0 & 10 \\
\hline & 2 & 10 & 10 & 10 & 10 & 10 & 10 & 10 & 10 & 10 & 0 \\
\hline \multirow{2}{*}{$\mathrm{EST}_{\mathrm{fl}}$} & 1 & 10 & 10 & 0 & 10 & 10 & 0 & 10 & 0 & 8 & 0 \\
\hline & 2 & 0 & 0 & 10 & 0 & 0 & 10 & 0 & 10 & 0 & 10 \\
\hline \multirow[t]{2}{*}{ PER } & 1 & 0 & 0 & 10 & 3 & 2 & 1 & 0 & 0 & 0 & 10 \\
\hline & 2 & 10 & 10 & 0 & 7 & 8 & 9 & 10 & 10 & 9 & 0 \\
\hline \multirow[t]{2}{*}{ PGM } & 1 & 0 & 0 & 0 & 0 & 0 & 0 & 0 & 10 & 0 & 0 \\
\hline & 2 & 10 & 10 & 10 & 10 & 10 & 10 & 10 & 0 & 10 & 10 \\
\hline \multirow[t]{2}{*}{ SOD } & 1 & 0 & 0 & 0 & 7 & 1 & 1 & 0 & 0 & 0 & 10 \\
\hline & 2 & 10 & 10 & 10 & 3 & 9 & 6 & 10 & 10 & 10 & 0 \\
\hline \multicolumn{2}{|c|}{ Genetic status } & $\mathrm{M}$ & $\mathrm{M}$ & $\mathrm{M}$ & $\mathrm{P}$ & $P$ & $\mathrm{P}$ & $\mathrm{M}$ & $\mathrm{M}$ & $\mathrm{M}$ & M \\
\hline
\end{tabular}

Table 5 Cumulative observed and expected frequencies of monomorphic and polymorphic clumps of Climacuim americanum. Expected counts are based on overall allele frequencies in each population for the total sample (a) or for a subset that is homogeneous with respect to varietal status (b). Log-likelihood ratio $\left(G^{2}\right.$, Bishop et al., 1975) test results comparing observed and expected ratios are also presented

a

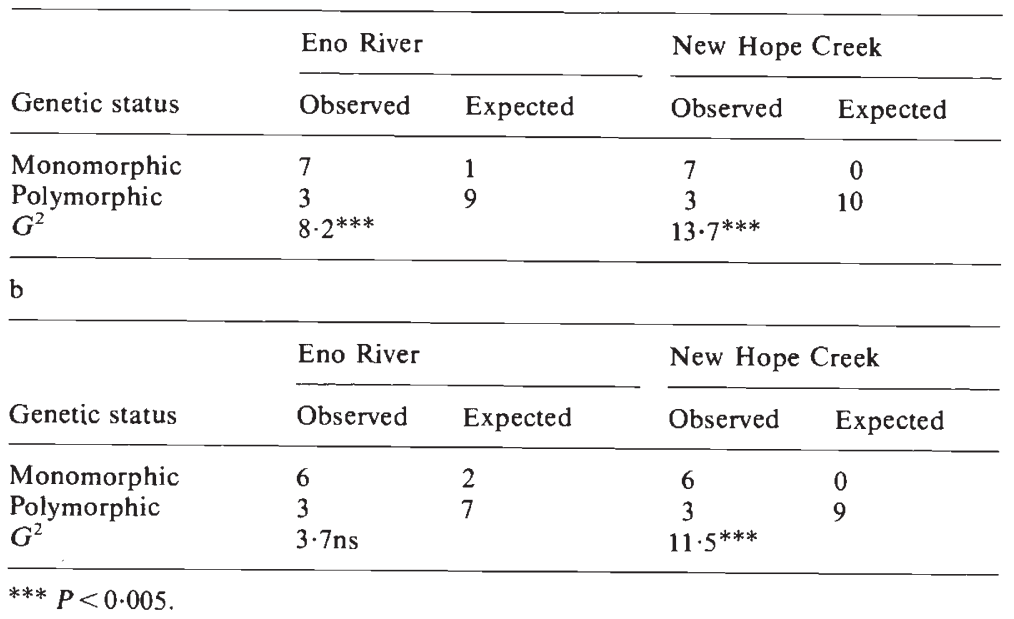

differences due to different morph types were thus eliminated, only the New Hope Creek sample showed a significant excess of monomorphism.

\section{DISCUSSION}

Our results indicate that clumps of Climacium americanum are not necessarily genetically homogeneous, although there is a tendency for them to be so. Most of the electrophoretically detectable variation in the two populations we studied occurred among the discreet clumps, yet some variation did exist within clumps. Electrophoretic surveys of moss populations are still limited in number, and care is often taken to avoid sampling within clumps (e.g., Daniels, 1982; and Shaw et al., 1987). In the only other study of which we are aware that has explicitly examined the genetic structure of moss clumps, Cummins and 
Wyatt (1981) obtained similar results demonstrating intra-clump variability in Atrichum angustatum.

Other studies of electrophoretic variation in moss populations have demonstrated surprisingly high levels of variation comparable in several cases to levels typical of highly outcrossed angiosperms (Wyatt, Stoneburner and Odrzykoski, 1989). Daniels $(1982,1985 a, b)$ has found variation in enzyme phenotype within populations of largely asexual species of Sphagnum in Great Britain and Scandinavia, but it is not clear how much of the variation occurred within physically discrete clumps. Krzakowa and Szweykowski (1979) have also demonstrated enzyme polymorphism in the largely asexual liverwort, Plagiochila asplenioides. Zielinski (1986) found genetic evidence of cross fertilization between individuals that were variable at a peroxidase locus within clumps of the liverwort, Pellia epiphylla. Lower but significant levels of cross fertilization occurred in a related species, Pellia borealis, again demonstrating that clumps of this liverwort are at least sometimes genetically heterogeneous.

Climacium is a small genus of three or four dioicous species. Populations of $C$. dendroides, a circumboreal relative of $C$. americanum, tend to show a strong female blas. In fact, most clumps of $C$. dendroides appear to be unisexual and the frequent absence of male plants directly limits sexual reproduction (Bedford, 1938). Transplantation of male plants into non-sporophyte producing female clumps resulted in successful sporophyte formation.

Comparable data on sex ratios in relation to sporophyte formation are not available for $C$. americanum. Our field observations, however, indicate that sexual reproduction is exceedingly rare in this species. We have observed sporophytes in only three populations in the Piedmont of North Carolina, although $C$. americanum is extremely abundant throughout the region. In our previous electrophoretic study (Shaw et al., 1987), one population along a stream feeding into the Eno River was selected for study because there were sporophytes present. This population, however, did not appear to be more variable than any of the other populations included in our studies.

Limited gamete dispersal distances characteristic of mosses (Anderson and Lemmon, 1974; Wyatt, 1977) make cross fertilization between clumps of species such as $C$. americanum extremely unlikely. Consequently, low levels of genetic variability within clumps clearly limit the possibility of genetic recombination during sexual reproduction in $C$. americanum and other species with similar clumped growth habits. Using cytological markers, Anderson and Lemmon (1974) found that an extensive population of the moss, Weissia controversa, consisted of numerous genetically discrete clumps, between which gene exchange appeared to be limited or absent under natural conditions.

As a means of dispersal and propagation, vegetative fragmentation is obviously effective for $C$. americanum, as shown by the abundance of nonsporophyte producing populations along streams throughout the Piedmont of North Carolina. The haploid nature of the gametophytes sampled made the determination of genetic uniformity of clumps quite robust. Even with a relatively small sample size within clumps and only six useful marker loci, it was possible to detect statistically significant departures from expected levels of polymorphism within clumps. Thus the statistical approach presented here should prove to be generally useful in studies of genetic variation in moss populations.

\section{REFERENCES}

ANDERSON, L. E. 1963. Modern species concepts: mosses. Bryologist, 66, 107-119.

ANDERSON, L. E. AND LEMMON, B. E. 1974. Gene flow distances in the moss Weissia controversa Hedw. J. Hattori Bot. Lab., 38, 67-90.

BEDFORD, T. H. B. 1938. Sex distribution in colonies of Climacium dendroides W. \& M. and its relation to fruit bearing. NWest Naturalist, 13, 213-221.

BELL, G. 1982. The Masterpiece of Nature: The Evolution and Genetics of Sexuality. University of California Press, Berkeley.

BISHOP, Y. M. M., FEINBERG, S. E. AND HOLLAND, P. W. 1975 Discrete multivariate analysis: theory and practice. MIT Press, Cambridge, Mass.

CORRENS, C. 1899. Untersuchungen uber die Vermehrung der Laubmoose durch Brutorgane und Stecklinge. G. Fischer, Jena, xxiv $+472 \mathrm{pp}$.

CRUM, H. A. 1973. Mosses of the Great Lakes Forest. Contrib. University Michigan Herbarium 10, 1-404.

CRUM, H. A. AND ANDERSON, L. E. 1981. Mosses of Eastern North America. Columbia University Press, New York.

CUMMINS, H., AND WYATT, R. 1981. Genetic variability in natural populations of the moss Atrichum angustatum. Bryologist, 84, 30-38.

DANIELS, R. E. 1982. Isozyme variation in British populations of Sphagnum pulchrum (Braithw.) Warnst. J. Bryol. 12, $1-11$.

DANIELS, R. E. 1985a. Isozyme variation in populations of Sphagnum recurvum var. mucronatum from Britain and Finland. J. Bryol., 13, 563-570.

DANIELS, R. E. $1985 b$. Isozyme variation in Finnish and British populations of Sphagnum compactum. Ann. Bot. Fenn., 22, 275-279.

DURING, H. J. AND VAN TOOREN, B. F. 1987. Recent developments in bryophyte population ecology. Trends in Ecology and Evolution, 2, 89-93. 
FELLER, W. 1968. An Introduction to Probability Theory and Its Applications. Wiley, New York.

KHANNA, K. R. 1964. Differential evolutionary activity in bryophytes. Evolution 18, 642-670.

KRZAKOWA, M. AND SZWEYKOWSK1, J. 1979. Isozyme polymorphism in natural populations of a liverwort, Plagiochila asplenioides. Genetics 93, 711-719.

LONGTON, R. E. 1976. Reproductive biology and evolutionary potential in bryophytes. J. Hattori Bot. Lab., 41, 205-223.

SHAW, J., MEAGHER, T. R. AND HARLEY, P. 1987. Electrophoretic evidence of reproductive isolation between two varieties of the moss, Climacium americanum. Heredity, 59, 337-343.

SILANDER, J. A. 1979. Microevolution and clone structure in Spartina patens. Science, 203, 658-660.

VRIJENHOEK, R. C. 1984. Ecological differentiation among clones: the frozen niche variation model. In Wohrmann, K. and Loeschcke, V. (eds) Population Biology and Evolution, Springer-Verlag, Berlin, pp. 217-231.
VRIJENHOEK, R. C., ANGUS, R. A. AND SCHULTZ, R. J. 1978 Variation and clonal structure in a unisexual fish. American Naturalist, 112, 41-55.

WYATT, R. 1977. Spatial pattern and gamete dispersal distances in Atrichum angustatum, a dioicous moss. Bryologist, 80, 284-291.

WYATT, R. 1982. Population ecology of bryophytes. J. Hattori Bot. Lab., 52, 179-198.

WYATT, R. AND ANDERSON, L. E. 1984. Breeding systems in bryophytes. In Dyer, A. F. and Duckett, J. G. (eds) The Experimental Biology of Bryophytes, Academic Press, New York, pp. 39-64.

WYATT, R., STONEBURNER, A. AND ODRZYKOSKI, I. J. 1989. Bryophyte isozymes: systematic and evolutionary implications. In Soltis, D. E. and Soltis, P. S. (eds) Plant Isozymes, Dioscorides Press, Portland, Oregon.

ZIELINSKI R. 1986. Cross-fertilization in the monoecious Pellia borealis, $n=18$, and spatial distribution of two peroxidase genotypes. Heredity, 56, 299-304. 